\title{
Germination of Forage Seeds Through Cattle as a Natural Propagator
}

\author{
Erico da Silva Lima ${ }^{1}$, Suzana Cristina Quintanilha ${ }^{1}$, Bruno Borges Deminicis ${ }^{2}$, \\ Vanessa Aparecida Feijó de Souza ${ }^{1}$, Tiago Neves Pereira Valente ${ }^{3}$, Andrea Roberto Bueno Ribeiro ${ }^{1}$, \\ Vitória Gallo Borges de Lima ${ }^{4}$, Agatha Nara Pirondi ${ }^{4} \&$ Adriano Adelson Costa ${ }^{1}$ \\ ${ }^{1}$ Programa de Mestrado Profissional em Saúde Ambiental, Centro Universitário das Faculdades Metropolitanas \\ Unidas (FMU), São Paulo, Brazil \\ ${ }^{2}$ Universidade Federal do Sul da Bahia (UFSB), Ilhéus, Brazil \\ ${ }^{3}$ Instituto Federal Goiano (IFGOIANO), Câmpus Posse, Posse, Brazil \\ ${ }^{4}$ Medicina Veterinária, Centro Universitário das Faculdades Metropolitanas Unidas (FMU), São Paulo, Brazil \\ Correspondence: Erico da Silva Lima, Programa de Mestrado Profissional em Saúde Ambiental, Centro \\ Universitário das Faculdades Metropolitanas Unidas, São Paulo, Rua Ministro Nelson Hungria, 541, Vila \\ Tramontano, CEP 05690050, Brazil. Tel: 55-11-33466200. E-mail: erico.lima@fmu.br
}

Received: September 10, 2018

Accepted: October 19, 2018

Online Published: December 15, 2018

doi:10.5539/jas.v11n1p231

URL: https://doi.org/10.5539/jas.v11n1p231

\begin{abstract}
Currently, sustainable practices combined with an efficient livestock can have benefits for farmers as observed in this study in which the animals themselves spread the seeds in the pasture in order to promote an addition of forage resources in the canopy. The objective of this study was to evaluate seed germination of three forage species [Avena strigosa Schreb (black oat), Calopogonium mucunoides (calopogonium) and Neonotonia wightii (perennial soybean)] following ingestion by cattle. The feces were collected from the animals at intervals of 6 hours up to 48 hours after the ingestion of the seeds. The feces were placed in beds in the field for further germination studies for the next 30,60 and 90 days (post-planting periods). No difference ( $P>0.05$ ) was observed between the treatments species or between post-planting periods of the evaluation. For all the studied seeds, the germination was only verified in the time of up to 30 days after the placement of the feces in the field, where black oats obtained numerically the highest accumulated percentage (during 48 hours) with 10\% of germinated seeds. It is concluded that the use of cattle as a disperser of forage seeds can help in the introduction of new forage in order to improve the production and the quality of the pastures. The moment of the cattle entrance in the pickets will depend on the forage species to be introduced and can vary from 6 to 12 hours after the intake of the seeds.
\end{abstract}

Keywords: forage seed ingestion by cattle, cattle dung, environmental sustainability, overcoming dormancy

\section{Introduction}

After seeding, it is important to have good establishment and a uniform and vigorous stand for a successful forage crop production. However, hardseedness can delay emergence following of forage crops. In many forage seeds, particularly forage legumes hard seed coat is one of factors that reduces seed germination (Rusdy, 2017). In such cases, under favorable environmental conditions, even when a seed is viable, the seed will not germinate. Without a good stand, the effectiveness of other agronomic inputs would be reduced, and usually such inputs may never compensate for the negative impact of a poor stand. The hard and impermeable seed coats restrict the entry of water and oxygen and offer high physical resistance to the growth of the embryo. This process slows the germination of the seeds, subjecting them for a long time to the exposure of adverse factors in the soil (Castro et al., 2017).

Using the bovine as seed disperser helps not only its dissemination, but also the acceleration of germination by the process of dormancy breaking of the ingested seed, which is due to the chemical processes that occur during digestion in ruminants. With this process, a considerable number of seeds would survive in the feces of the cows and later be dispersed in different areas of the pasture paddock (Deminicis, 2005).

In this sense, the survival of the seeds after passage through the digestive tract of some animals may improve forage diversity in a pasture where ruminants have been used as natural dispersers of these seeds. This would 
consequently lead to an improvement in pasture yield, quality and animal production, as well as a reduction in production costs, more so, when compared using fertilizer application as a method of pasture rejuvenation (Gardener et al., 1993).

The objective of this study was to evaluate the seed germination of Avena strigosa Schreb (black oats), Calopogonium mucunoides (calopogonium) and Neonotonia wightii (perennial soybean) when fed to grazing cows with the goal of improving an old forage stand. Do black oats haven't hard seed issues but it will be used to increase the dry mass and nutritive value of pasture in the autumn and winter where there is a shortage of forage plants in the pasture.

\section{Method}

\subsection{Geographic Location}

The experiments were conducted in the dairy cattle, horticulture and chemical laboratory sectors of the Fazenda Escola da Etec Benedito Storani, in Jundiaí city, State of São Paulo, Brazil (23 $11^{\prime}$ S and $46^{\circ} 53^{\prime}$ W) in an altitude of $761 \mathrm{~m}$.

\subsection{Seed Source and Agronomic Characteristics of Black Oat, Calopogonium and Perennial Soybean Forage}

Seeds of Avena strigosa Schreb (black oats), Calopogonium mucunoides (calopogonium) and Neonotonia wightii (perennial soybean) were collected from a seed company (Sementes Piraí). The initial agronomic characteristics are shown in Table 1.

Table 1. Agronomic characteristics of Avena strigosa Schreb (black oat), Calopogonium mucunoides (calopogonium) and Neonotonia wightii (perennial soybean) forages

\begin{tabular}{llll}
\hline \multirow{2}{*}{ Agronomic characteristics } & \multicolumn{3}{c}{ Species } \\
\cline { 2 - 4 } & Avena strigosa Schreb & Calopogonium mucunoides & Neonotonia wightii \\
\hline Germination (\%) & 75 & 60 & 60 \\
Purity (\%) & 95 & 85 & 95 \\
Cultural Value (\%) & 71.25 & 51 & 57 \\
Fresh matter yield (t/ha) & 30 to 60 & 20 to 30 & 20 to 30 \\
Potential N fixation (kg N/ha) & - & 60 to 80 & 60 to 80 \\
Weight of 1,000 seeds $(\mathrm{g})$ & 20 to 23 & 12 to 13 & 5 to 6 \\
Sowing rate $(\mathrm{kg} / \mathrm{ha})$ & 65 to 80 & 8 to 10 & 7 to 8 \\
\hline
\end{tabular}

Note. ${ }^{*}$ Cultural Value $(\%)=$ Purity $(\%) \times \%$ Germination $(\%) / 100$.

\subsection{Animal and Seed Testing}

For this study, three 2-yr old crossbred heifers (Holstein $\times$ Zebu) cattle (Bos taurus $\times$ Bos indicus) weighing about $300 \mathrm{~kg}$ live weight were used. This study followed the ethical principles of the ethics committee for animal experimentation (CEUA) of the university, under the protocol $n^{\circ}$. 011/15-CEUA. Prior to the experiment, the animals were raised on elephant grass pasture (Pennisetum purpureum), receiving water and mineral mixture at will.

The animals were randomly assigned to a $4 \times 8 \mathrm{~m}$ individual pen with cemented floor and clay roof. While in the pens, the animals received a diet consisting of corn silage, in which the amount provided was $10 \%$ in relation to their live weight, twice daily and provided with water at will for a week (adaptation period).

In the experimental phase, each animal received 200 seeds of a forage species that was mixed with 200 grams of concentrate to promote ingestion. The animals were fed the seed-concentrate mixture on 5 different occasions-repetitions (referred to as $1^{\text {st }}, 7^{\text {th }}, 14^{\text {th }}, 21^{\text {st }}$ and $28^{\text {th }}$ day). On the $1^{\text {st }}$ day, the seeds were given to the animals for 6 hours to get them accustom to the seeds. Six hours after the seeds have been introduced, the feces of these animals were collected, and this continued at intervals of 6 hours until 48 hours after the ingestion of the seeds (i.e. 6, 12, 18, 24, 30, 36, 42, 48 hours).

At each collection, the fecal cakes containing the seeds according to the treatments tested were taken to the horticulture section of the farm. The fecal materials were placed in beds $(1 \mathrm{~m} \times 3 \mathrm{~m})$ made of substrate based on $50 \%$ pine bark and $50 \%$ coconut fiber, with $0.5 \mathrm{~m} \times 0.5 \mathrm{~m}$ spacing provided between beds. The beds were $20 \mathrm{~cm}$ in height, a sufficient height for the initial development of the seedlings. 
Soon after the deposition of the fecal cakes in the beds, the beds were watered and the dungs were maintain a good moisture condition. Seed germination count started 30 days later and continued at 60 and 90 days post fecal excretion. Only seed germination data for the first 30 days have been provided here (see Table 2 below). The $\%$ germinated seeds were determined through the count of the number of seeds germinated in the bovine feces in each period of time, divided by the intake (200 seeds) of the animals [(Number germinated seeds/200) $\times 100 \%$ ]. After a few days post-planting were observed the presence of fecal cakes at the beginning of fermentation, as well as ant attack in the beds and these were thought to have affected the emergence of the seeds in the fecal cakes after 30 days. In addition, after the ingestion of the seeds, mastication and digestion damage can occur, which can damage the seeds (Deminicis et al., 2009), being that the legumes need overcome dormancy so that the germination can occur efficiently. Such factors may have contributed to the absence of seed germination after 30 days.

The bays in which the animals were confined in the experimental period were next to each other, and attached to them contained a $16 \times 35 \mathrm{~m}$ earthen pick, so that all animals could remain loose and together between one repetition and another. The animals continued to gain access to the aforementioned feed and water at will.

The experimental design was completely randomized design, with three treatments (forage species) and five replications/receptions per animal.

\subsection{Statistical Analysis}

The collected data were analyzed by means of an inferential statistical analysis, in which the percentages of germination between the different treatments (species) and between the reading moments (hours) were compared. The analyses were carried out with the aid of the R Project v. 3.2.2 (Lowry, 1992; John et al., 2004).

First, in order to assess normality, the Shapiro-Wilk test was conducted at 0.05 significance level. In all cases, no adherence to the Normal distribution was observed $(\mathrm{p}>0.05)$, which directed the choice by non-parametric tests.

The comparison of independent variables was performed using the Kruskal Wallis test $(\alpha=0.05)$, while the comparison between the study moments was conducted according to the Friedman test ( $\alpha=0.05)$. To adjust the type I error of the analysis was used the Bonferroni correction (Bonferroni, 1936).

The logistic regression of the data was also performed, considering the time at the end of the experiment as the independent variable and the percentage of germination as dependent. The respective equations and determination coefficients $\left(\mathrm{R}^{2}\right)$ were obtained.

\section{Results and Discussion}

No difference was observed between the treatments (species) or between seed germination count days post fecal excretion (Table 2).

Table 2. Percentage of germinated seeds (of the total administered via concentrate) of Avena strigosa Schreb (black oat), Calopogonium mucunoides (calopogonium) and Neonotonia wightii (perennial soybeans), at 30 days post fecal excretion

\begin{tabular}{lllllll}
\hline \multicolumn{7}{c}{ Treatments } \\
\hline Moments & Black oat & Calopogonium & Perennial soybean & Total, \% & SE & P value \\
\hline From 0 to $6 \mathrm{~h}$ & $0.00 \mathrm{aA}$ & $0.00 \mathrm{aA}$ & $0.00 \mathrm{aA}$ & 0.00 & 0.00 & - \\
Between 6 and $12 \mathrm{~h}$ & $0.40 \mathrm{aA}$ & $0.80 \mathrm{aA}$ & $0.00 \mathrm{aA}$ & 5.40 & 0.23 & 0.581 \\
Between 12 and $18 \mathrm{~h}$ & $2.00 \mathrm{aA}$ & $0.80 \mathrm{aA}$ & $1.20 \mathrm{aA}$ & 18.2 & 0.35 & 0.522 \\
Between 18 and $24 \mathrm{~h}$ & $2.40 \mathrm{aA}$ & $1.20 \mathrm{aA}$ & $0.40 \mathrm{aA}$ & 18.2 & 0.58 & 0.548 \\
Between 24 and 30h & $1.60 \mathrm{aA}$ & $0.40 \mathrm{aA}$ & $0.00 \mathrm{aA}$ & 9.10 & 0.48 & 0.081 \\
Between 30 and 36h & $2.00 \mathrm{aA}$ & $2.00 \mathrm{aA}$ & $0.40 \mathrm{aA}$ & 20.0 & 0.53 & 0.0435 \\
Between 36 and $42 \mathrm{~h}$ & $1.20 \mathrm{aA}$ & $1.20 \mathrm{aA}$ & $1.60 \mathrm{aA}$ & 18.2 & 0.13 & 0.918 \\
Between 42 and 48h & $0.40 \mathrm{aA}$ & $0.40 \mathrm{aA}$ & $1.60 \mathrm{aA}$ & 10.9 & 0.40 & 0.267 \\
Total & 10.0 & 6.80 & 5.20 & 100 & 1.41 & - \\
\hline
\end{tabular}

Note. * Means followed, in the same column, by the same lowercase letters, do not differ from each other by the Kruskal-Wallis test at 0.05 of significance; ** Means followed, in the same line, by the same capital letters, do not differ from each other by the Kruskal-Wallis test at 0.05 of significance. SE: Standard error of the mean. ${ }^{1}$ Total $=$ total percentage of treatments at each moment. 
Though, in the present study, it seems impossible to evaluate seed germination/emergence beyond 30 days after the feces were placed the beds, but earlier study by Deminicis et al. (2009) showed that there was germination for the studied species [Leucaena leucocephala (leucena), Clitorea ternatea (cunhã), Calopogonium mucunoides (calopogônio), Neonotonia wightii (soja perene) and Macrotyloma axillare (macrotiloma)], as well as, in the 30-day period, from 30 to 60 and from 60 to 90 days post seed ingestion, in relation to the percentage of germination of seeds in the bovine feces.

Avena strigosa Schreb had the highest accumulated percentage (up to $48 \mathrm{hrs}$ ), with $10 \%$ germinated seeds, followed by Calopogonium mucunoides legumes, with $6.8 \%$ and Neonotonia wightii with $5.2 \%$. As Avena strigosa Schreb obtained the largest number of seedlings emerged in fecal cakes, it could be assumed that the passage of the seeds of this species of grass by the digestive tract of cattle did not so much affect its germination and subsequent emergence. However, for perennial soybeans, the passage through the digestive tract may have negatively influenced their germination and emergence.

In agreement, Almeida et al. (2015) when evaluating the dispersal of tropical forage legume seeds after ingestion by cattle, obtained after a period of $48 \mathrm{~h}$ for complete defecation of the seeds, a greater accumulated percentage of emerged seedlings of the calopogonium species with $1.64 \%$, and the worst result for perennial soybean seeds with $0.06 \%$. According to the authors, the passage through the digestive tract of cattle may have contributed to the reduction of germination of the legume seeds studied.

According to Jones and Simão Neto (1987), germination of legume seeds may be related mainly to the efficiency of dormancy breaking, through the passage through the digestive tract of the cattle and the climatological and nutritional influence to which the legumes were submitted. According to the same authors, after the ingestion of seeds, chewing and digestion damage occur, and the percentage of seeds damaged by the animal is related to its size, shape and hardness of the coating, the proportion of seeds in the diet, the animal species, the quality of the diet consumed and the time of their stay in the tract directory. In addition, there are toxic compounds in bovine feces that act to inhibit the germination of seeds (Hoekstra et al., 2002).

According to the results obtained in this present study, it is suggested that the size of the seeds was not a relevant factor for the germination of the same in the feces, because the species that presented the best results was Avena strigosa Schreb one size higher when compared to the seeds of the forage Calopogonium mucunoides and Neonotonia wightii.

A similar result was also found by Deminicis et al. (2009), when studying the percentage of germinated seeds (from the total administered via the esophageal cannula) of Leucaena leucocephala, Clitorea ternatea, Calopogonium mucunoides, Neonotonia wightii and Macrotyloma axillare, at 30 days post fecal excretion in fecal plaques of cattle, since in his work he observed that the species that presented the highest percentage of germinated seeds was perennial soybean with $8.63 \%$, followed by the Clitoria ternatea L., with $8 \%$, and calopogonium $3.88 \%$, according to the author, the species that presented the best results, are differentiated by the size of their seeds.

Although there was no difference between species, when evaluating their germination in the feces (Table 2), each one obtained its highest germination at a different time, which can serve as a basis for the decision making by a producer when using animals as a propagating agent of the seeds.

In the present study, for black oat and calopogonium, no germination was observed in the first 6 hours after supplying the seeds to the cattle, and for the perennial soybean, germination was observed in the fecal cakes only after 12 hours after ingestion of the seeds. Therefore, in view of these results, the animals will of entrance in the pickets that intende to introduce the seeds of the forages, in a period of 12 hours after ingestion of the perennial soybean and 6 hours after ingestion of the calopogonium and black oat. Thus, the seeds germination may contribute even more with the production and quality of pasture.

Deminicis et al. (2009) observed that in the rejects of the first six hours after ingestion of the seeds by the cattle, no germination observed for the forage soybean perennial, and for the calopogonium, germination only verified at 12 hours after the seeds were supplied to the cattle. A similar result found by Silva (2013), who, when studying the dispersion of Clitorea ternatea, stylistic and kudzu seeds in pastures by small ruminants, observed that in fecal cakes collected 6 hours after ingestion, no seed was found either. It was believed that six hours were not sufficient for the beginning of the expulsion of the seeds in the feces of the sheep, for the three species evaluated.

For black oats, the best performance with respect to its germination began observed from six to 12 hours $(0.4 \%)$ after ingestion of the seeds, and its best germination occurred in the range of 18 to 24 hours (2.4\%), with a slight 
decrease from 24 to 30 hours (1.6\%). The same was observed for calopogonium, whose germination also began from 6-12 hours $(0.8 \%)$ after ingestion of the seeds, with better germination in the interval between 30 and 36 hours $(2 \%)$ (Table 2).

It was observed that the perennial soybean seeds presented lower performance when compared to the two species already mentioned, in which the germination of their seeds began in the interval between 12 and 18 hours (1.2\%) after ingestion of the seeds (Table 2).

Deminicis (2005) observed that the period when feces were excreted, which presented the highest percentage of germinated seeds (from the germinated total in the evaluation period up to 30 days) was from 18 to 24 hours, with $27 \%$ of the germinated seeds, followed by the period from 12 to 18 hours, with $20 \%$ of the seeds.

The equations describing the behavior of the number of seeds/hours germinated in the bovine feces were obtained through regression analysis. The regression curve for the germinated seeds in the feces of the three species / hour presented in Figure 1.

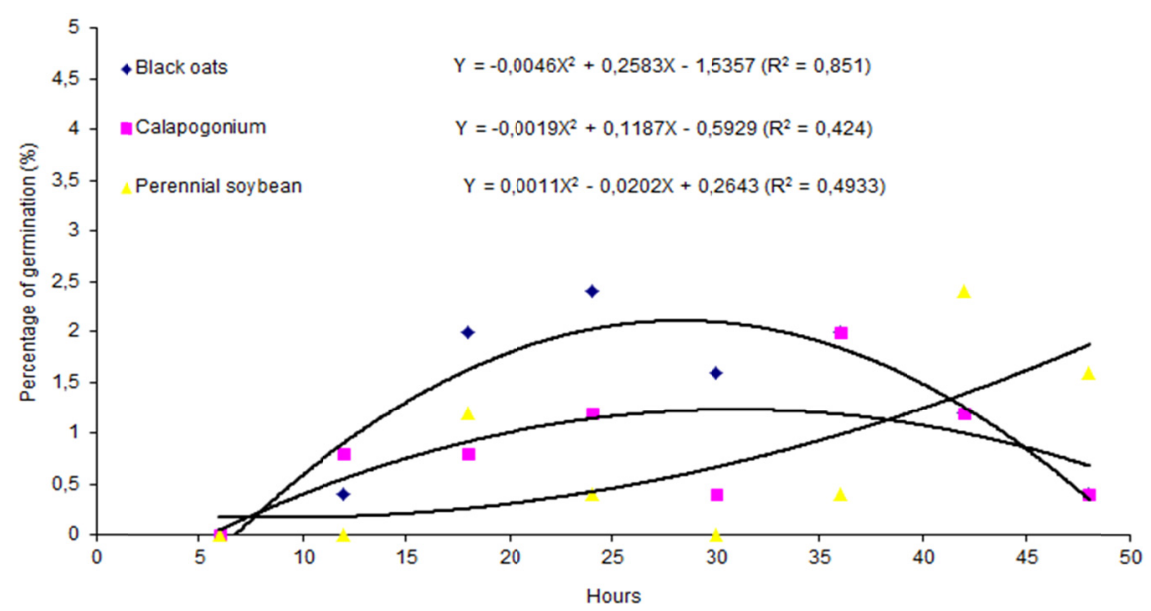

Figure 1. Regression curves for the percentage of Avena strigosa Schreb (black oats), Calopogonium mucunoides (calopogonium) and Neonotonia wightii (perennial soybean) germinated in bovine feces, in the period in which they were excreted

Although there was no significant difference between treatments, it was observed that black oat seeds presented the best performance in relation to their germination, and that germination began to be observed from 6 to 12 hours after excretion of the feces, and its best germination occurred in the interval between 18 and 24 hours after excretion of the feces, with a slight fall from 24 to 30 hours. The same pattern was observed for calopogonium, where its germination also began observed from six to 12 hours after excretion of the feces, with better germination in the interval between 30 and 36 hours after excretion of the feces. It was observed that the perennial soybean seeds were those that presented inferior performance when compared to the other two species tested here, in which the beginning of the germination of their seeds occurred in the interval between 12 and 18 hours after the excretion of the feces.

In relation to the treatment with black oats, the $\mathrm{R}^{2}=0.851$, indicating that the period predicted the percentage of germination in $85.1 \%$. Both calopogonium and perennial soybean had lower determination coefficients, being 0.424 and 0.493 respectively (Figure 1). Therefore, it could be said that oats have an optimal upper range (18 to 24 hours) after ingestion of the seeds.

Some factors may have been determinant for the germination percentage results verified in the present study, among them: the positioning of the seeds in the fecal cake, the thickness of the fecal cake, another factor of extreme importance, related to the composition of the tegument of the seeds that is, related to the hardness of the integument (Simão Neto \& Jones, 1987).

\section{Conclusions}

The Avena strigosa Schreb (black oat) was the one that presented numerically the highest accumulated percentage of seeds germinated in the bovine feces. This may be viable for farmers who use this specie for adding grass to the pasture. 
The use of cattle as a disperser of forage seeds can help in the introduction of new forage in order to improve the production and the quality of the pastures.

The moment of the cattle entrance in the pickets will depend on the forage species to be introduced and can vary from 6 to 12 hours after the intake of the seeds.

\section{References}

Almeida, J. C. C., Silva, T. O., Nepomuceno, D. D., Rocha, N. S., Araújo, R. P., Pereira, T. P., ... Abreu, J. B. R. (2015). Dispersion and persistence of tropical forage leguminous after ingestion by cattle. Bioscience Journal, 31, 867-874. https://doi.org/10.14393/BJ-v31n3a2015-22743

Bonferroni, C. (1936). Teoria statistica delle classi e calcolo delle probabilita. Pubblicazioni del $R$ Istituto Superiore di Scienze Economiche e Commericiali di Firenze, 8, 3-62.

Castro, S. D., Araujo, E. F., Borges, E. E. L., \& Amaro, H. T. R. (2017). Caracterizacão da testa de sementes de Apuleia leiocarpa (vogel) macbr. após superacão de dormencia. Ciencia Florestal, 27, 1061-1068. https://doi.org/10.5902/1980509828681

Deminicis, B. B. (2005). Germinação de leguminosas forrageiras tropicais sob tratamentos químicos, fisicos e biológicos (Mestrado em Zootecnia). Retrieved from http://r1.ufrrj.br/wp/ppgz/files/2015/05/54-BrunoBorges-Deminicis.pdf

Deminicis, B. B., Almeida, J. C. C., Malafaia, P. A. M., Blume, M. C., Abreu, J. B. R., \& Vieira, H. D. (2009). Germinacão de sementes em placas fecais bovinas. Archivos de Zootecnia, 58, 73-84. https://doi.org/ $10.4321 / \mathrm{S} 0004-05922009000100008$

Gardener, C. J., McIvor, J. G., \& Jansen, A. (1993). Passage of legume and grass seed through the digestive tract of cattle and their survival in faeces. Journal of Applied Ecology, 30, 63-74. https://doi.org/10.2307/ 2404271

Hoekstra, N. J., Bosker, T., \& Lantinga, E. A. (2002). Effects of cattle dung from farms with different feeding strategies on germination and initial root growth of cress (Lepidium sativum L.). Agriculture, Ecosystems and Environment, 93, 189-196. https://doi.org/10.1016/S0167-8809(01)00348-6

John, N., Kutner, M., Wasserman, W., \& Nachtsheim, C. (2004). Applied Linear Statistical Models (5th ed.). Columbus: McGraw-Hill.

Jones, R. M., \& Simão Neto, M. (1987). Recovery of pasture seeds ingested by ruminants. The effects of the seed in diet and quality on seed recovery from sheep. Australian Journal of Experimental Agriculture, 27, 253-256. https://doi.org/10.1071/EA9870253

Lowry, S. C. (1992). Use and misuse of multiple comparisons in animal experiments. Journal of Animal Science, 70, 1971-1977. https://doi.org/10.2527/1992.7061971x

Rusdy, M. (2017). A review on hardseedness and breaking dormancy in tropical forage legumes. Livestock Research for Rural Development, 29, 237.

Santos, T. O., Morais, T. G. O., \& Matos, V. P. (2004). Mechanical scarification in Chichá seeds (Sterculia foetida L.). Revista Árvore, 28, 1-6. https://doi.org/10.1590/S0100-67622004000100001

Silva, T. O. (2013). Estudo para dispersão de fabáceas em pastagens por pequenos ruminantes (Doutorado em Produção Vegetal). Retrieved from http://www.uenf.br/Uenf/Downloads/PRODVEGETAL_3434_13736 51397.pdf

Simão Neto, M., Jones, R. M., \& Ratcliff, D. (1987). Recovery of pasture seed ingested by ruminants. 1. Seed of six tropical pasture species fed to cattle, sheep and goats. Australian Journal of Experimental Agriculture, 27, 239-246. https://doi.org/10.1071/EA9870239

\section{Copyrights}

Copyright for this article is retained by the author(s), with first publication rights granted to the journal.

This is an open-access article distributed under the terms and conditions of the Creative Commons Attribution license (http://creativecommons.org/licenses/by/4.0/). 